\title{
Gábor KOZMA*
}

\section{PLACE MARKETING IN HUNGARY: THE CASE OF DEBRECEN}

\begin{abstract}
After the political transformations in East-Central Europe local authorities were forced to realise that they have to employ more active policy, and consequently, the use of place marketing became more popular. The study examines one particular city in Hungary, Debrecen, and concentrates on two areas. First, it presents what methods were employed in an attempt to attract economic players and tourists, and to increase the satisfaction of existing target groups. Secondly, it evaluates the steps taken: how characteristic were the tools used in Debrecen in other Hungarian cities, and what positive and negative features of marketing activity can be identified. Key words: place marketing, Debrecen.
\end{abstract}

\section{INTRODUCTION}

From the early 1980s the attitude of the local authorities has undergone a transformation on two levels. First, they started to pay more attention to their environment, to the processes which take place there and the analyses of how these events influence their own future. Secondly, while earlier they regarded the development of services and infrastructure and the control and regulation of the development as their primary task, from the beginning of the decade they had to realise that they must show much more initiative. As Harvey stated, the leaders of the cities should acquire an entrepreneurial approach instead of the formerly applied managerial approach (Harvey, 1989).

These changes raised the interest of the researchers dealing with urban and regional policy, and since several elements of the new activity resembled the

\footnotetext{
* Gábor KOZMA, Department of Social Geography and Regional Development Policy, University of Debrecen, Hungary, 4010 Debrecen, P.O. Box 9; e-mail: gkozma@ delfin.klte.hu
} 
marketing of the traditional consumers' goods, they started talking about the selling and marketing of territorial units. By the late 1980s and early 1990s a new terminology was also created: the term 'place/city marketing' became much more wide-spread in the English-speaking countries.

Place/city marketing, as a new research area soon gained popularity, and more and more publications appeared whose titles included the words marketing and selling together with the name of territorial units (especially place and city). The similar titles, however, did not cover the same content: in most cases, the authors referred to different things when applying the terms.

In the beginning, place marketing was identified with promotional activities (Bailey, 1989; Bartels and Timmer, 1987; Burgess, 1982; Gold and Ward, 1994). Another group of the authors (e.g. Smyth, 1994) approached place marketing primarily from the aspect of architecture, while the researchers of another group (including Varady and Raffel, 1992; Walsh, 1989) primarily focused on the activities of the local authorities within the city.

The spread of the idea of the wider interpretation of place/city marketing is connected to Ashworth and Voogd $(1988,1990)$. They pointed out the most important characteristics of the producers of the cities as goods to be sold and its consumers, the various types of city marketing policies applicable by the local authorities and the relations between city marketing and planning.

In the 1990s, the comprehensive interpretation of place marketing became widespread in the United States too, where Kotler et al. (1993) published their work. It is one of its greatest merits that it deals with the stages of product development in great depth pointing out that the marketing activity can only be successful if it relies on a place which is attractive from many aspects.

These works (Asworth and Voogd, 1988, 1990 and Kotler et al.) had an immense impact and consequently the books (e.g. Kearns and Philo, 1993) and articles introducing case studies (e.g. Madsen, 1992; Paddison, 1993; Short et al., 1993; Ward, 1998) published in the 1990s discussed the topics of place marketing from this aspect.

In the new millennium, however, the term 'place branding' also began to appear in the literature, which was regarded as a new phase of the application of place marketing (Kavaratzis, 2007). The primary objective of place branding is to create an emotional and psychological connection, a link between the 'consumers' and the given place with the help of communication activities, organising events and the appropriate built environment.

The purpose of this study is to present the application of the principles of place marketing in the case of a Hungarian city, Debrecen, which is regarded by many today as one of the most successful settlements of the country. Debrecen is the second largest city in Hungary (with a population of 204,000), and is situated in the eastern part of the country. 
The study consists of three main parts: first, I will explore the various crisis phenomena and the underlying factors that the city of Debrecen had to deal with in the early 1990s. Secondly, the methods that were employed in order to attract economic actors and tourists, and to increase the satisfaction of various target groups will be presented. Thirdly, the steps already takenwill be analysed and evaluated: how characteristic were the tools used in Debrecen in other cities of Hungary, and what positive and negative features of the marketing activity of the local authority can be identified.

\section{THE CRISIS OF THE 1980S}

The Hungarian and international events of the second half of the 1980s had detrimental consequences for Debrecen from the point of view of both industry and tourism, and resulted in an increase of unemployment.

In the period of socialist industrialisation between 1949 and 1973, approximately 25,000 new jobs were created, and as a result of political and economic changes, the fate of enterprises became dubious for two reasons. First, companies established strong commercial links with the surrounding COMECON countries, and their exports were primarily aimed at these markets. As a result, the disintegration of this organisation, and especially the economic collapse of the Soviet Union caused serious problems with the markets.

Secondly, further aggravating the problem was the unfavourable distribution of plants in terms of their size: as a result of the socialist industrialisation, large plants were present in the city in a proportion above the national average. Amid these changed circumstances, when quick reaction to changes became a basic precondition of successful operation, companies lost their competitiveness, since in the multiple-level of decision-making systems they were only able to adapt to new challenges slowly.

The events of the last years of the 1980s and the first years of the 1990s also caused serious problems in the field of tourism. In earlier period, there was a significant proportion among tourists coming to the city who were Hungarian citizens, people coming in the framework of trade union-organised holidays, and groups from the socialist countries. The general impoverishment of the Hungarian population, the collapse of the majority of large companies, and the problems that appeared in other socialist countries had a negative impact on all three groups, and as a consequence the number of visitors coming to Debrecen decreased. 


\section{USING ELEMENTS OF CITY MARKETING}

In the course of their marketing activities local authorities and other organisations active in this field take the individual steps in a given sequence. The first important task is to prepare a theoretical analysis providing a foundation for the subsequent phases of work; then, relying on the findings of these, to develop the given area, as a product, in an effort to build up a versatile product; finally, the availability of the endowments at hand needs to be communicated to the target groups.

The first important phase of place marketing means carrying out all the theoretical studies that can serve as the foundation of the actual developments and the communication activities. These studies consist of three parts:

- the endowments of the given area have to be analysed;

- the marketing policy to be followed must be chosen;

- the groups need to be defined that they wish to attract to the given area.

There were several theoretical studies prepared after the political changes that aimed at identifying the endowments of Debrecen and exploring possible direction of development:

1. The Regional Tourism Development Plan of Debrecen (1997).

2. The Economic Development Concept of Debrecen (2000).

3. The Medium-Term Tourism Development Concept of Debrecen (2001).

4. The Tourism Development Concept and Development Programme of Debrecen (2004).

Application for the title of European Capital of Culture (2004/2005).

These studies identified the endowments of the city, including its strengths and weaknesses, the opportunities available and the threats impending. The analysis of the internal environment revealed in all cases the role of the city as a regional centre, the intellectual background offered by the University of Debrecen, and the availability of the airport, while the weaknesses included the weak links between the university and economic life, and the low entrepreneurial activity. In studies prepared in the 1990s, the weaknesses also included the poor accessibility of the city, the inappropriate training structure of the university (absence or lack of law, economic education), while in the analyses of the new millennium, these aspects, as a result of the developments that took place in the meantime, were rather among the strengths of the city.

In the context of the analysis of the external environment, the evaluation of the city went through some changes. In the 1990s, Debrecen was still regarded as a starting point of commerce toward Romania; however, today, it is mainly the threats associated with this neighbouring country (especially in terms of attracting away businesses) that dominate analyses. The studies invariably listed the new trends of tourism (the development of health-related sectors) as 
opportunities from which the city can profit; at the same time, the regional policy support provided by the European Union also appeared in the new millennium as a potential source of local developments (the North Great Plain Region, which also includes Debrecen, is among theleast developed regions of the EU).

The studies suggested quality-oriented marketing policy in tourism and a diversification marketing policy in other sectors of the economy. In the former case, it was emphasised that the city can only retain the existing consumers (e.g. those interested in cultural, conference, fitness and wellness tourism) if it improves its offering, while in the latter case the experts emphasised the importance of attracting new sectors (especially companies producing high added value), which is only possible if certain conditions are in place.

The second very important element of place marketing is product development, in the framework of which the endowments of the places are developed. In the course of this the local authorities and the other organisations may concentrate on four large sets:

- they must ensure the infrastructure necessary for the development;

- they must create the proper institutional background;

- they must take part in the organisation of various programmes;

- they must create an attractive built environment.

Within the framework of the development of the infrastructure, the local authorities need to concentrate primarily on two fields: they need to create the human infrastructure and the physical infrastructure for the development.

With respect to the human infrastructure, the local authority of Debrecen mainly aimed at the development of the education. In the 1990s, the main attention was given to to the broadening of the one-sided higher education (with no faculties of law and economy). In the spirit of the above, the local authority played a decisive role in achieving that the university should be given the use of the barracks earlier used by the Soviet army (this is where the newly established Faculties of Economics, Law and Public Health, as well as the new dormitory were established), and also helped attract professors to the city by way of providing housing for them. The good relationship between the city and the university also remained in the new millennium (the two parties concluded cooperation agreements in 2000 and in 2003, and the existence of the university played an important role in attracting several companies to Debrecen); in addition, the local authority, having recognised the demands of the companies operating in the city, started to place a bigger emphasis on secondary education. First, with the introduction of English-language education, the city tried to enhance the attractiveness of Debrecen among the managers of multinational companies (from 2011, it will be possible to take an international baccalaureate in Debrecen); secondly, programmes targeting the development of sectors representing the strengths of the city have been launched (training for nurses in 
English - caring for foreign patients at the clinic; English-language secondary school chemical industry training - the demands of TEVA pharmaceuticals company; starting new programmes in the information technology secondary school - the demands of IT Services).

With respect to physical infrastructure, an important task concerning all target groups is the improvement of accessibility, in the framework of which the local authority of Debrecen mainly concentrated on two areas. First, aware of the fact that multinational companies, in case of their new investments, only take into consideration settlements within a distance of 15-20 minutes from motorways, the city exercised lobby activities in order to accelerate the connection of Debrecen to the European network of motorways. This task was made more difficult by the fact that the national plans in the middle of the 1990s still did not include a motorway connection between Budapest and Debrecen. However, at the pressure of the city, this route was also included in the plans and by the end of 2005, the new motorway was opened. Secondly, the local authority made efforts to connect the airport located to the south of the city into international air traffic. In the interest of the above, it purchased the airport in 1994 and carried out major developments, as a result of which the airport currently occupies the third position in the world in terms of its volume of passengers, and also satisfies the Schengen criteria.

In other fields of the development of the physical infrastructure it can already be clearly distinguished whether the primary aim was the satisfaction of the demands of economic actors or those of tourists. In terms of economic actors, the local authority primarily aimed at making available real properties with the necessary infrastructure (water, sewage, gas, electricity, telecommunication network) to companies wishing to settle in the city. In the above spirit, over the past 10 years, two business parks were established in the city (one is owned by the local authority, the other by the University of Debrecen), which provided for companies the necessary conditions.

In case of tourists, the primary aim was the implementation of investments that offer Debrecen a competitive advantage in various areas of tourism. Related to the field of sport tourism are the new athletic stadium, the indoor sports swimming pool and Fönix Hall (this latter is the second largest such facility of the country), important projects in terms of business tourism were Kölcsey Convention Centre and Hotel Lycium Business Hotel. As far as cultural tourism is concerned, MODEM (Museum of Modern Arts), while in terms of health tourism the construction of the Aquaticum Mediterranean Pleasure Bath and the Aquaticum Debrecen Thermal and Wellness Hotel and the modernisation of the medicinal bath, should be mentioned.

The creation of the proper institutional background affects two areas. First, the local authorities should create the necessary conditions within their own sphere, which means that organisational units should be created within the office 
that are in charge of this task. An examination of the organisational structure of the local authority of Debrecen reveals that between 1990 and 2000, employees working in the field of city marketing were scattered at various units (e.g. Department of Economic Organisation, Mayor's Secretariat) and there was little coordination between them. The real changes happened at the beginning of the new millennium when the City Marketing Team was organised. This unit, supervised by the Mayor's Secretariat, as well as the communication counsellor appointed in 2006, deal with the issues of encouraging investments, tourism and foreign relations.

Secondly, it is important to create such organisations which are ready to react to the arising opportunities quickly and contribute to the development of the city with their conscious activities. It was in the interest of satisfying the above expectations that Debreceni Asset Management Inc. integrating the municipally owned companies, was established in 2000. The company currently has 13 member companies, from among which 5 are important from the point of view of city marketing: Airport Debrecen Ltd. (operating the airport), Debrecen Regional and Innovation Industrail Park Ltd. (operating the business park), 'Cívis House' Property Management Inc. (renovation of the inner city area), Debrecen Medical Bath Inc. (operating Aquaticum Debrecen Thermal and Wellness Hotel, Aquaticum Mediterranean Pleasure Bath and Hotel Lycium) and DEHIR Ltd. (the communication activities of the company).

The next element of the product development is constituted by the various programmes and events which can be classified on the basis of two criteria (Michalkó, 2007): we can differentiate between cultural, commercial and sporting events, and between permanent (annual or biennial) and one-time events. If we examine the programmes held in Debrecen, we can see that the city has events in almost all segments that attract visitors even from beyond the borders of the country. From among the permanent cultural events, we should mention the Flower Carnival, organised in 2008 for the 39th time (attracting approximately 200,000 visitors), the Debrecen Jazz Days, the Bartók Béla International Choir Competition, which is of European reputation, the International Military Band Festival, while the important one-time cultural events include the concerts of Bryan Adams, Deep Purple and Iron Maiden, the show of David Copperfield, and the art exhibition titled 'The Real da Vinci', which was staged in the city in 2007 after Florence and Tokyo.

Permanent commercial events include various exhibitions and fairs, which in line with international tendencies - mainly concentrate on certain special fields (the most important among them is the Farmer Expo International Agricultural and Food Industry Exhibition). It was partly due to the presence of the university, and partly to the significant improvement of the conditions that the city provided a venue for an increasing number of international conferences (one-time commercial events) (e.g. INTERREG IIIC - Flapp Conference). 
Relying on its existing facilities (Főnix Hall, athletic stadium, indoor swimming pool), Debrecen has hosted more than 10 international sporting events since 2000 (e.g. International Youth Athletic Championship, Men's and Women's Gymnastics European Championship, IIHF Division I Ice Hockey World Championship), and the city also submitted a (finally unsuccessful) bid for hosting the 1st Youth Olympic Games.

Within the framework of product development, the formation of an attractive built environment is of special importance, and two methods are available for the local authorities to realise this. First, they can place novelty and modernity into the focus following the principles of the presently worldwide ground-gaining postmodernism. The other option could be the proper exploitation of the relics of the architectural past, that is the so-called heritage planning (Molnár, 2005).

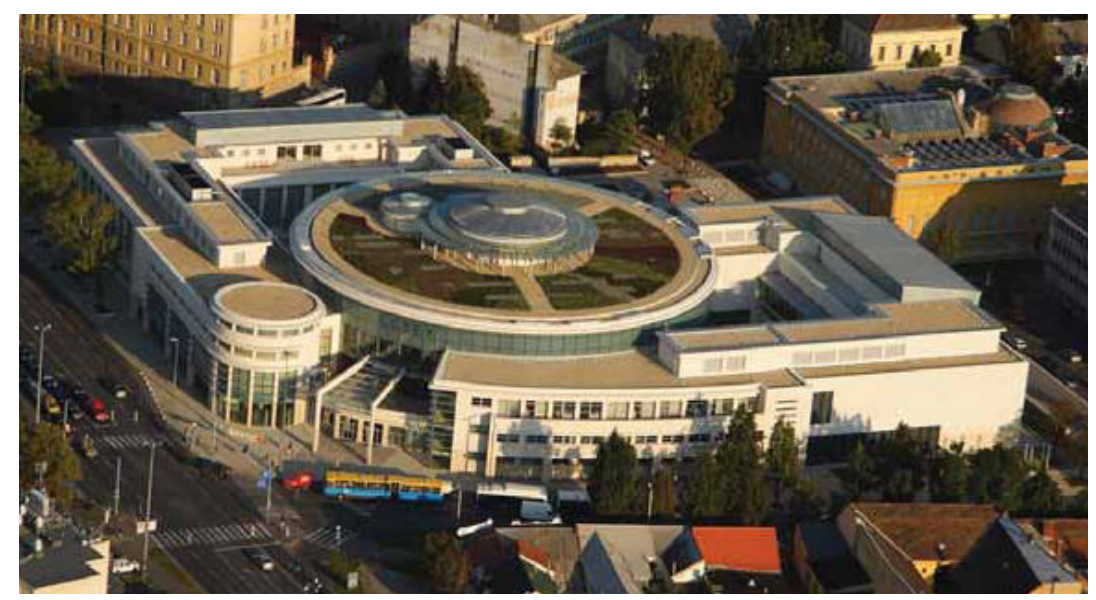

Photo 1. The building complex of Kölcsey Convention Center - MODEM - Hotel Lycium

For reasons related to natural endowments (lack of stones for construction) and historical background (destruction of the social era also in the inner city areas), Debrecen has no conterminous historical district, and so the heritage of the past can hardly be used in city marketing. Consequently the activities of the local authority was concentrated on two areas. First, it aimed at the renovation of the existing monuments, and secondly, in order to enhance the attractiveness and liveability of the city centre, it set as an objective the banning of motor vehicles from the city centre since the early 1990s. After the creation of the necessary preconditions (building of appropriate byroads and underground garages), it was in the first years of the new millennium that the transformation of the main square of the city into a pedestrian zone took place, which soon became a favourite meeting point of the locals and a main revenue for different programmes. Debrecen is not in a better situation in terms of modern 
architecture either: none of the new buildings erected in recent years (the building complex of Kölcsey Convention Center - MODEM - Hotel Lycium, photo 1, Debrecen Forum Shopping and Entertainment Centre) have architectural values that would in themselves enhance the attractiveness of the city.

The last phase of place marketing is the communication activity which generates various opinions. First, it is one of the most spectacular elements for the outside world and many experts identify place marketing with this. Secondly, there are more and more researchers representing the notion that communication activity is only one element of place marketing (Young and Kaczmarek, 1999), and its importance should not be exaggerated.

Communication activities may be divided into two stages. First, a message has to be designed which is able to convince the target groups about the advantages of a given place. Secondly, this message has to be disseminated to them in the most efficient way.

In the framework of their communication activities, local authorities frequently strive to create slogans and logos that summarise the endowments of the given place and elevate them from among the competitors.

Until the second half of the 1990s, the idea for the application of such elements of communication was not raised, and it was only in 1998 that the slogan and logo were created. The slogan 'Debrecen - Converging the lines' was fundamentally not specific to a target group; it aimed to call the attention of all target groups to the settlement. It referred to the fact that this place is the meeting point between East and West, tradition and modernity, tourist and spectacle etc. It was soon found out, however, that this slogan had been previously used by another city in Hungary (Győr), and so any further use was abandoned.

In the early years of the millennium, it was rather target group specific slogans that were created. In the field of tourism, the city used for several years the slogan 'Debrecen - The City dressed in the Sun', which dates back to the 18th century (a Dutch traveller used these words to describe the city). In the field of the economy, there were no conscious efforts to create a slogan, as attempts we can only mention the titles of publications discussing the endowments of the city: 'Debrecen, the City of Great Opportunities', 'Debrecen: Your Choices Our Success'.

In the centre of the logo (figure 1) that was used for a long time was the Reformed Church, as the most famous building of the city; the Sun showing between the two towers is a reference to continuous rebirth, and thus also to the myth of the phoenix, the bird also featured in the historic coat of arms of the city, while the green field in front of the church may evoke associations to the Great Forest. 


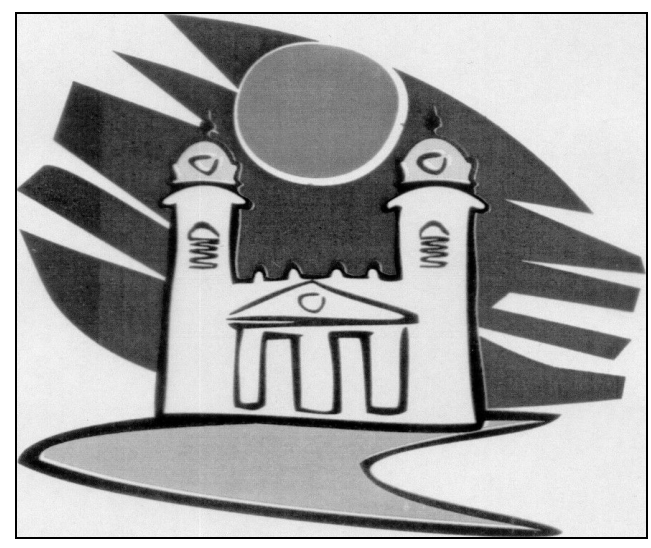

Fig. 1. The tourism logo of Debrecen, created in 1998

With respect to the content of the message, a peculiar duality can be observed both in case of economic actors and tourists: there are certain elements that had already been important in the middle of the 1990s, while other elements only emerged in the new millennium.

In the messages communicated toward economic actors, there has been much attention given from the very beginning to the favourable geographical location of the city (point of departure toward Romania and Ukraine), its advanced network of educational institutions (with higher education given special significance within that), as well as the existence of Debrecen Airport. In the past 5 or 6 years, the new elements include the presentation of specific investment opportunities (the facilities available at the business parks), the improving accessibility on motorways, emphasising the high living standards that is available in the city, the strong links between the university and the economy, and the listing of the international companies that operate in the city.

In the messages targeted at tourists, the historic monuments of the city (Reformed Church, Reformed College), exhibitions (e.g. Déri Museum), and the events held in the city (e.g. Béla Bartók International Choir Competition, Flower Carnival) have always played important roles. In the new millennium, the above elements remained and were expanded (e.g. new events - Cívis Promenade, exhibitions in MODEM), and new elements were also added, such as the opportunities offered by Fönix Hall, Kölcsey Convention Center and Aquaticum Mediterranean Pleasure Bath.

If we analyse the tools that are used to communicate these messages, we can conclude that from among advertisements of different types Debrecen only used billboards: in recent years, several billboards called attention to the tourism offering of city both within Hungary (e.g. Budapest, Miskolc) and abroad (in large cities near the border in Romania). 
As a result of technological development, the Internet today now also offers opportunities to local authorities to communicate their messages. Having recognised this, the local authority of Debrecen launched its own website in 1997 (www.debrecen.hu), which has since been significantly redesigned on several occasions.

Traditional tools of the communication activity include publications that play a significant role in the case of Debrecen and their review allows us to make to some important observations. First, a considerable improvement over time can be observed: the materials made in the 1990s were usually of smaller scale, printed on normal paper and with negligible graphical illustration. By contrast, today, the A4-size publications printed on glossy paper and richly illustrated with maps and photographs dominate.

Secondly, significant specialisation can also be observed in case of these publications: separate materials are prepared for tourists and for economic actors, and in fact in both cases, further segmentation can also be observed (e.g. separate publications were prepared by Aquaticum and by the airport also).

In the framework of Public Relations activities, the local authority is trying to establish good relations with mass communication, as an efficient group of opinion-formers (a separate press team now works within the Mayor's Office), and also to make the best use of sister city relationships (Debrecen has more than 10 sister cities): it very often participates on travel exhibitions organised in these cities.

\section{CONCLUSION}

The analysis of the work of the local authority of Debrecen in the field of place marketing reveals that even though the leaders of the city recognised the importance of this area already in the early 1990s, conscious and effective activities only started towards the end of the decade. First, it was declared that the city set as its primary objective to attract high added value sectors, in which effort it devoted to higher education; secondly, in the area of tourism, the city declared its intention to concentrate on health, fitness and wellness, cultural, sport and business tourism. In addition, it was also at this time that the investment projects aimed at improving the city as a product commenced, which serve the purpose of differentiating itself from the competitors so that Debrecen can offer a unique product for the target groups: 1999 - airport development, 2002 - modernisation of the medicinal bath, 2003 - Aquaticum Mediterranean Pleasure Bath, 2006 - Kölcsey Convention Centre, 2006 - MODEM, 2006 Hotel Lycium, 2007 - indoor sport swimming pool. At the same time, these two 
elements were also very closely linked, since the local authority decisively implemented projects that improved the attractiveness of the city for the wellqualified workforce employed in high added value sectors.

If we compare the activities of the city with those of other Hungarian cities, there is hardly any difference with respect to the theoretical studies and the communication activities: these other settlements also carried out similar analyses and used more or less the same methods for calling the attention of the target groups.

In terms of product development, however - in addition to the existing similarities (e.g. lobbying in the interest of improving the accessibility of the city, creation of business parks, creation of pedestrian zones in the inner cities, development of health, fitness and wellness tourism, organising cultural events) - the local authority of Debrecen also tried several unique measures not attempted elsewhere in order to differentiate the city from the competition. One of these is the development of the airport on which the city has spent approximately 5 billion HUF since 1994. Second, the construction of Kölcsey Convention Centre, but especially of Hotel Lycium and MODEM should be mentioned, which are projects that are hardly typical of local authorities in Hungary.

Third, a pioneering act in Hungary was the creation of the Debrecen Asset Management Inc., whose investment projects greatly contributed to the improvement of the competitiveness of the city, and which also engages in communication activities. Fourth, the activities of the local authority in Debrecen in the field of sports events can also be regarded as a unique tool, which was successful in attracting tourists to the city especially outside the high season, and which also contributed to making the city better known.

The first real results of the marketing activities of the city could be observed by the middle of the first decade in the new millennium, which was manifested in terms of the economy partly by way of new companies settling in the city and partly by those already here expanding their activities. National Instruments (USA), a manufacturer of electronic components, which moved its production activities to Debrecen in 2001, also brought its logistical headquarters to the city from Amsterdam in 2005, followed in 2007 by the customer service and the unit responsible for software development. With an investment of 15 billion HUF by 2010, TEVA, the Israeli pharmaceuticals company, will double its manufacturing capacity and expand its R\&D activities, thereby creating 420 new jobs, while the Hungarian pharmaceuticals manufacturer, Richter Gedeon will commence in 2009, also with an investment of 15 billion HUF, to build a biotechnological plant of which only 2 currently exist in Europe.

In terms of information technology and financial services, the results of the efforts of the local authority are shown by the fact that the study of Deloitte 
Global Location and Facilities Services conducted in 2005/2006 comparing large cities in Hungary ranked Debrecen among the top five settlements (these are the so-called 'pearl cities') where the situation is appropriate for the settling down of regional service centres. In the light of this it is not surprising that the German company T-Systems and its Hungarian subsidiary, IT Services Hungary Ltd., established in 2008 a service centre employing a thousand highly-trained information and communication technology professionals, while commercial, technological and product development regional business support centre of British Telecom Global Services also employs 250 professionals in a similar field.

Examining the gross added value indicators of the companies (table 1) we can find that, in comparison with the situation in the second half of the 1990s, Debrecen significantly improved its position and it currently stands at the second place in the rank of the five Hungarian regional centres.

Table 1. Changes in the gross added value/person index figure in Debrecen and in Hungary from 1997 to 2006 (Debrecen=100\%)

\begin{tabular}{|l|r|r|r|r|r|r|r|r|r|r|}
\hline \multicolumn{1}{|c|}{ Region } & 1997 & 1998 & 1999 & 2000 & 2001 & 2002 & 2003 & 2004 & 2005 & 2006 \\
\hline Miskolc & 74.0 & 81.1 & 86.0 & 65.8 & 52.1 & 49.3 & 55.1 & 58.1 & 59.5 & 57.9 \\
Szeged & 114.8 & 117.2 & 123.9 & 99.1 & 74.7 & 72.2 & 75.7 & 67.5 & 67.3 & 60.8 \\
Pécs & 117.3 & 115.9 & 127.8 & 103.9 & 112.1 & 119.5 & 142.5 & 121.8 & 75.4 & 61.4 \\
Györ & 251.3 & 336.4 & 422.6 & 390.7 & 253.8 & 236.4 & 261.4 & 231.4 & 226.0 & 242.9 \\
Magyarország & 109.2 & 114.7 & 122.4 & 111.7 & 86.6 & 86.1 & 95.0 & 91.1 & 88.7 & 91.5 \\
\hline
\end{tabular}

Source: TEIR.

Significant development in comparison with the second half of the 1990s can also be observed with respect to tourism. First, after recovering from the decrease experienced in the first few years of the new millennium, the number of tourism nights spent at commercial accommodations increased by approximately $150 \%$ (table 2), and a particularly positive feature is that the growth in case of hotels representing higher revenues was even higher. Secondly, the rate of growth was above the Hungarian average, which means that the positions of Debrecen also improved in national comparison. Thirdly, the tourism potential of Debrecen is also reflected by the fact that, as a result of a 6 billion HUF private investment, the second 5-star hotel of Eastern Hungary was opened in Debrecen in 2008, which proves that private capital also has trust in the endowments of the city. 
Table 2. The number of tourism nights spent at various types of accommodations in Debrecen between 1997 and 2007

\begin{tabular}{|c|c|c|c|c|}
\hline Year & A & B & C & D \\
\hline 1997 & 261,529 & 139,645 & 1.50 & 1.38 \\
\hline 1998 & 268,118 & 158,244 & 1.59 & 1.51 \\
\hline 1999 & 273,211 & 172,679 & 1.58 & 1.60 \\
\hline 2000 & 349,812 & 200,801 & 1.90 & 1.75 \\
\hline 2001 & 355,422 & 211,707 & 1.91 & 1.82 \\
\hline 2002 & 351,042 & 227,081 & 1.90 & 1.94 \\
\hline 2003 & 310,799 & 199,962 & 1.67 & 1.71 \\
\hline 2004 & 302,270 & 223,743 & 1.60 & 1.77 \\
\hline 2005 & 305,682 & 233,369 & 1.55 & 1.72 \\
\hline 2006 & 398,686 & 318,322 & 2.03 & 2.32 \\
\hline 2007 & 393,062 & 304,510 & 1.95 & 2.16 \\
\hline
\end{tabular}

Explanation: A - the number of guest nights spent at commercial accommodations, $\mathrm{B}-$ the number of guest nights spent in hotels, $\mathrm{C}-$ the number of guest nights spent at commercial accommodations in Debrecen/the number of guest nights at commercial accommodations in Hungary (\%), D - the number of guest nights spent in hotels in Debrecen/the number of guest nights in hotels in Hungary (\%).

Source: TEIR.

Apart from the results, however, several problems could also be mentioned. First of all, somewhat deteriorating the competitiveness of the city is the 'low' level of utilisation of the airport. Even though there have been attempts at launching scheduled commercial flights (the Debrecen-Munich and the Debrecen-Budapest flights operated for 4-5 months), the bulk of the volume of traffic is provided by charter flights carrying tourists. The annual volume of 50-60 thousand tourists, however, does not ensure economically efficient operation, and in the opinion of local business leaders, this is an obstacle in the way of the city becoming a real regional centre. Secondly, in the field of events, apart from the Flower Carnival of 1-2 days, the city failed to establish regular, longerlasting events, which would attract significant crowds also internationally.

Thirdly, since most of the investments mentioned above were financed by the city itself, the volume of the debts of both the local authority and of Debrecen Asset Management Inc. significantly increased, which necessitated the rethinking of the strategy concerning the taking out of further loans. Fourthly, certain problems could also be observed in the course of the communication activities. For one thing, both the local authority and Debrecen Asset Management Inc. are engaged in communication activities, and in several cases this causes overlaps 
and tensions between the two organisations. Further, the last economically focused publication was issued in 2005, and since many of the investment projects since that time that indicate the success of the city are not included in that, such a delay may be harmful to the competitiveness of the city. Finally, in the course of the renewal of the website in 2007-2008, the earlier English version was deleted; however, the English pages of the new website were not available for about $9-10$ months.

\section{REFERENCES}

ASHWORTH, G. J. and VOOGD, H. (1988), 'Marketing the City: Concepts, Process and Dutch Applications', Town Planning Review, 59 (1), pp. 65-79.

ASHWORTH, G. J. and VOOGD, H. (1990), Selling the City: Marketing Approaches in Public Sector Urban Planning, London: Belhaven.

BAILEY, J. T. (1989), Marketing Cities in the 1980s and Beyond, Chicago: American Economic Development Council.

BARTELS, C. P. A. and TIMMER, M. (1987), 'City Marketing: Instruments and Effects', Paper to be presented at the European Congress of the Regional Science Association.

BURGESS, J. A. (1982), 'Selling Places: Environmental Images for the Executive', Regional Studies, 16 (1), pp. 1-17.

GOLD, J. R. and WARD, S. V. (ed.), (1994), Place Promotion: The Use of Publicity and Marketing to Sell Towns and Regions, Chichester: Wiley.

HARVEY, D. (1989), 'From Managerialism to Entrepreneurialism: The Transformation in Urban Governance in Late Capitalism', Geografiska Annaler, 1, pp. 3-17.

KAVARATZIS, M. (2007), 'City Marketing: The Past, the Present and Some Unresolved Issues', Geography Compass, 1/3, pp. 695-712.

KEARNS, G. and PHILO, C. (ed.), (1993), Selling Places: The City as Cultural Capital. Past and Present, Oxford: Pergamon Press.

KOTLER, P., HAIDER, D. H. and REIN, I. (1993), Marketing Places: Attracting Investment, Industry and Tourism to Cities, States and Nations, New York: Macmillan.

MADSEN, H. (1992), 'Place-marketing in Liverpool: A Review', International Journal of Urban and Regional Research, 16, pp. 633-640.

MICHALKÓ, G. (2007), Magyarország modern turizmusföldrajza (The modern tourism geography of Hungary), Budapest-Pécs: Dialóg Campus.

MOLNÁR, E. (2005), 'The Conditions of the Pottery Industry Development in Mezőtúr', [in:] SÜLI-ZAKAR, I. (ed.), Cross-Border Co-Operations, Debrecen: University of Debrecen, pp. 238-242.

PADDISON, R. (1992), 'City Marketing, Image Reconstruction and Urban Regeneration', Urban Studies, 30 (2), pp. 339-350.

SHORT, J. R., BENTON, L. M., LUCE, W. B. and WALTON, J. (1993), 'Reconstructing the Image of an Industrial City', Annals of the Association of American Geographers, 83 (2), pp. 207-224.

SMYTH, H. (1994), Marketing the City: The Role of Flagship Developments in Urban Regeneration, London: E \& FN Spon. 
VARADY, D. P. and RAFFEL, J. A. (1995), 'Selling Cities: Attracting Homebuyers through Schools and Housing Programmes', Albany: States University of New York Press.

WALSH, K. (1989), Marketing in Local Government, London: Longman.

WARD, S. V. (1998), Selling Places: The Marketing and Promotion of Towns and Cities 18502000, London: E \& FN Spon.

YOUNG, C. and KACZMAREK, S. (1999), 'Changing the Perception of the Post-Socialist City: Place Promotion and Imagery in Łódź. Poland', The Geographical Journal, 165 (2), pp. 183-191. 